Article

\title{
Evaluation of Interactive Website Design Indicators for e-Entrepreneurship
}

\author{
Chih-Chao Chung ${ }^{1}$, Li-Chung Chao ${ }^{1}$, Chin-Hui Chen ${ }^{2}$ and Shi-Jer Lou ${ }^{3, *}$ \\ 1 Institute of Engineering Science and Technology, National Kaohsiung First University of Science and \\ Technology, Kaohsiung City 824, Taiwan; u9915916@nkfust.edu.tw (C.-C.C.); chaolc@nkfust.edu.tw (L.-C.C.) \\ 2 Department of Modern Languages, National Pingtung University of Science and Technology, \\ Pingtung 912, Taiwan; irenechen@mail.npust.edu.tw \\ 3 Graduate Institute of Technological and Vocational Education, National Pingtung University of Science \\ and Technology, Pingtung 912, Taiwan \\ * Correspondence: lou@mail.npust.edu.tw; Tel.: +886-8-770-3202
}

Academic Editor: Giuseppe Ioppolo

Received: 23 February 2016; Accepted: 6 April 2016; Published: 12 April 2016

\begin{abstract}
Using an analytic network process (ANP) as an analytical tool, this study aims to construct an ANP evaluation model of interactive website design indicators. Through a review of the literature, interactive website design of e-entrepreneurship is generalized to the following dimensions: (1) Design; (2) Checking; (3) Service; (4) Interactive; and (5) Promotion, including 19 design indicators. The research is conducted for a case company. According to the findings, the model helps the case company review its current execution of interactive website design indicators and the experts' opinions of the importance of interactive website design indicators. In addition, by comprehensive comparison, it confirms key design indicators and analyzes the managerial implications to help the case company set up precise strategic planning and resource distribution to enhance corporate operational performance and competitiveness.
\end{abstract}

Keywords: website design; interaction; e-entrepreneurship; analytic network process

\section{Introduction}

Upon the arrival of the global digital era, access to information on the internet has attracted human resources and commercial trade. According to the statistics provided by Emarketer in June, 2014, there were 10.3 billion buyers in the B2C (Business to Customer; an E-commerce mode providing a shopping environment, enabling customers to purchase and pay online, saving time and space for both parties and increasing transaction efficiency) worldwide e-commerce market [1]. This finding indicates the prosperity of e-commerce. Hence, new forms of business combining the internet and commerce have emerged and started to create a global e-commerce industry [2]. The e-commerce entrepreneurs changed the rules of business competition and created new types of businesses that had not previously been observed [3]. They also produced many opportunities to make a great fortune [4]. However, according to the Ministry of Economic Affairs, Taiwan, online stores in Taiwan are not considered to be very successful. In 2014, those which were profitable comprised only $34.9 \%$ of all the online shops [1]. The above finding indicates that successful e-commerce is challenging, given that the market is extremely competitive. This is because e-entrepreneurship has the following characteristics: (1) diversity of objects; (2) immaturity of innovation; and (3) unstructured ecosystems [5]. Research has also suggested that business opportunities derived from the internet are dynamic, fast growing, and highly competitive. Customers have learned how to use the internet to collect information and take advantage of increasingly easy-to-use online payment mechanisms. Furthermore, the whole business process, including conceptualization of products, design, manufacturing, marketing, and eventually 
customer purchases, can be operated online. The barriers between enterprises and the outside world have been removed, and the original ways of operating a business can be gradually replaced [6]. Therefore, it is important to identify correct business strategies to operate online stores. Given the above arguments, this research aims to explore the evaluative indicators of website design for e-entrepreneurship in Taiwan to increase the possibility of success.

Information spreads quickly in the online world. With the click of a computer mouse, a customer can compare prices online and switch to another online shop to purchase the same product. The cost of such switching behavior is low, so it is rather difficult to expect loyalty from customers engaged in online shopping [7]. Park and Reber [8] analyzed the websites of 100 of the Fortune 500 companies and argued that the interactions between companies and their clients are important for enhancing trust, commitment, and building relationships. The results indicate that the internet has changed the ways businesses are operated because customers can have more interactions with companies via more channels. Therefore, with the world placing more value on interactions with customers, companies need to learn how to treat individual customers' needs more carefully $[9,10]$. Furthermore, customers should be included as a part of the value chain, and interactive websites or online shops should have greater convenience, attractiveness, and safety so that customer loyalty is increased [11]. By employing the strategy of differentiation from competitors, companies can make profits more easily [12,13].

Given the above arguments, we need to consider many factors of successful e-entrepreneurship when constructing interactive websites for e-commerce. We also have to understand customers' online shopping behavior to develop the correct strategies to maintain and develop relationships with them [14] to increase the possibility of success. Therefore, this study employed analytic network processes (ANP) [15] as the approach to evaluate design indicators of interactive websites. ANP was considered appropriate because they enable researchers to address questions with multiple purposes, principles, and behaviors. This present study also aims to develop an evaluation model to assess design indicators of interactive websites in terms of its reflection of the trends of current e-commerce. The findings can be used as a reference for companies to introduce e-entrepreneurship. The purposes of this study are as follows:

(1) Study important indicators of website design for e-entrepreneurship;

(2) Construct an ANP assessment model of website design; and

(3) Analyze the managerial implications of e-entrepreneurship website design indicators.

\section{Literature Review}

This study reviews the literature related to e-entrepreneurship, website design, website interaction, and ANP to generalize the website design content of e-entrepreneurship and characteristics of ANP.

\section{1. e-Entrepreneurship}

Yesil [16] suggested that online stores are in virtual space, and customers can purchase goods or services directly or trade with buyers or sellers. Brynjolfsson and Smith [17] have described e-malls, which are based on virtual stores. In online stores, multimedia catalogues and videos of products are presented, which customers can browse. Entrepreneurship emphasizes novelty, new products, new processes, or new markets to create wealth $[18,19]$. Based on the above, this study defines e-entrepreneurship as follows. The effective creation of value in e-commerce includes a number of elements, namely, (1) Overview; (2) Selection; (3) Concluding; (4) Cooperation; and (5) Exchange [12]. Table 1 summarizes the advantages of e-entrepreneurship as opposed to traditional entrepreneurship. These advantages, as shown in Table 1, include saving on personnel costs and rental fees of physical shops, as well as building a frictionless business environment [20]. Furthermore, e-entrepreneurs can have product information spread widely within a short period of time by updating the websites of online shops [21]. e-Entrepreneurship also has additional merits, for instance, breaking national boundaries to maintain business competitiveness, shortening the supply chain between sellers and 
buyers to reduce transaction costs [22], responding to customers' feedback and complaints promptly without restrictions of time and space, constructing good customer relationships to enhance retention and, lastly, strengthening product publicity and the company image. As opposed to traditional media, online interaction can help companies approach customers more easily and closely [23]. Therefore, this study uses the above advantages as the evaluative indicators of interactive websites for e-entrepreneurship.

Table 1. Advantages of e-entrepreneurship.

\begin{tabular}{ll}
\hline \multicolumn{1}{c}{ Categories } & \multicolumn{1}{c}{ Descriptions } \\
\hline 1. Use of space & $\begin{array}{l}\text { Online stores do not have the limitation of physical space, and they can be } \\
\text { further expanded. }\end{array}$ \\
\hline 2. Customer sources & The consumers of online stores are not limited geographically. \\
\hline 3. Service offering & $\begin{array}{l}\text { Offered with automatic service by computer system and service quality is } \\
\text { more consistent. }\end{array}$ \\
\hline 4. Exhibition of goods & $\begin{array}{l}\text { Using multimedia techniques, goods can be presented to customers more } \\
\text { authentically. }\end{array}$ \\
\hline 5. Time limit & $\begin{array}{l}\text { Online stores do not have the limitation of operating hours, and the trading } \\
\text { can be at any time. }\end{array}$ \\
\hline 6. Arrangement of personnel & $\begin{array}{l}\text { Online stores are based on design maintenance and management personnel. } \\
\text { The clerks are not needed. }\end{array}$ \\
\hline 7. Expenditure of costs & The costs of rental, human affairs, and equipment of online stores are lower. \\
\hline
\end{tabular}

\subsection{Website Design}

The design of websites for online shops must include success factors of establishing a company in the New Economy, namely, (1) Management; (2) Product; (3) Processes; (4) Finances; and (5) Market Access/Network [12]. It is argued that website designs should not be carried out for several parts that are independent from each other. On the contrary, they should highlight the concept of value networks [5]. Therefore, Angehrn's [24] ICDT model (Information, Communication, Distribution, Transaction) should be taken into account as the blueprint to design the value networks for online stores. The model can help companies cope with the competitive pressure and the impact of the internet, redesign commercial activities, take hold of emergent business opportunities of internet development, and become leaders of the e-market [25]. ICDT models have the following characteristics: (1) by internet marketing and advertising, they provide information of products and services to the public; (2) through interaction on the internet, they enhance communication between buyers and sellers. The purpose is to coordinate business activities and control and influence business decision-making to establish long-term and intense cooperation; (3) using the internet, they distribute and sell products and provide service to lower delivery and logistic costs to increase business efficiency and competitiveness; and (4) they practice transactions of business processes, lower transaction costs, improve transaction quality, emphasize security of product transactions and completeness of after-transaction service [26,27]. Furthermore, it is advised that the strategies of operating online shops should include increasing opportunities to interact with customers by correctly identifying target customers, offering pleasant purchasing experiences, improving operational processes including customers, ensuring customer autonomy, and helping customers receive the service they need [28,29]. Additional considerations include offering complete product information, customer service, transaction safety, and convenience [30]. Furthermore, providing customers with individualized information, multiple payment options, allowing them to return goods if not satisfied, and offering price comparison mechanisms are also important strategies to be considered [31].

Given the above, this study uses ICDT as the fundamental framework for website design. The framework incorporates the complete Net Economy, the successful establishment of an efficient 
website for e-entrepreneurship, and setting up a customer-oriented online shop, all of which serve the purpose of increasing the possibility of successful e-entrepreneurship.

\subsection{Website Interaction}

Jensen [32] suggested that interaction means behavior and reaction exchanged between at least two people in specific situations. Rafaeli [33] defined interaction in computer communication as a correlation among a series of information. It is a correlation between information transmitted by the third party (or the following parties) and the previous information transmitted. As indicated by Srinivasan, Anderson, and Ponnavolu [34], two factors can positively enhance customer loyalty; that is, providing appropriate service, transaction service, and constant interactions with customers. Hence, by interaction strategy and customer interaction, online stores can enhance customers' consumption and loyalty. In other words, in comparison to physical stores, by application of information technology and various interactive channels, online stores can immediately respond to customers' questions without temporal and space limitations and can provide them with appropriate goods by active marketing. This reinforces the consumers' positive comments on the online stores [35]. Ghose and Dou [36] studied 101 corporate websites of goods and classified website interaction into five categories: (1) customer support; (2) marketing study; (3) customized selection; (4) advertising and promotion; and (5) entertainment, including 23 functions. Based on the research findings of Ghose and Dou [36], interaction has a positive relationship between attraction and evaluation of websites. Moreover, factors of successful e-entrepreneurship are no longer limited to website presentation or low pricing strategies but, more importantly, the service quality of online shopping [37]. Given that, this study emphasizes the importance of considering the interactive element in the design of websites for e-entrepreneurship to ensure the establishment and maintenance of customer relationships and, hopefully, to create differentiation and product profits as a consequence.

Given the above arguments, this study summarizes the findings in the existing literature into five categories of design indicators of interactive websites for e-entrepreneurship. As a consequence, a total of 24 design indicators are listed in Table 2. Based on the 24 indicators, an expert questionnaire survey was conducted to identify which are the essential design indicators for the ANP evaluation model.

Table 2. Descriptions of interactive website design indicators of e-Entrepreneurship.

\begin{tabular}{|c|c|c|}
\hline \multicolumn{2}{|c|}{ Interactive Functions } & Descriptions \\
\hline \multirow{4}{*}{$\begin{array}{l}\text { Design } \\
\text { (DS) }\end{array}$} & $\begin{array}{l}\text { 1. Webpage announcement } \\
\text { (WA) }\end{array}$ & $\begin{array}{l}\text { It announces the latest information and activities for users to approach } \\
\text { the website and attract new members. }\end{array}$ \\
\hline & $\begin{array}{l}\text { 2. Simple operation of } \\
\text { interface (SOI) }\end{array}$ & $\begin{array}{l}\text { When connecting with related information, users will not be lost on the } \\
\text { webpages, and they can return to the website after connecting with others. } \\
\text { It can avoid users' lower intention of purchase by complicated operation. }\end{array}$ \\
\hline & 3. Website browsing (WB) & $\begin{array}{l}\text { By the navigation function of websites, users can be familiar with the } \\
\text { website framework. Website navigation can be shown by an online map. }\end{array}$ \\
\hline & $\begin{array}{l}\text { 4. Opinion survey on } \\
\text { websites (OSW) }\end{array}$ & Ask users to give opinions or suggestions on website content. \\
\hline \multirow{5}{*}{$\begin{array}{l}\text { Checking } \\
\text { (CK) }\end{array}$} & 1. Product searching (PS) & $\begin{array}{l}\text { The goods on websites are classified with the indication of specifications, } \\
\text { patterns, and functions for the users' checking and purchase. }\end{array}$ \\
\hline & 2. Price checking $(\mathrm{PC})$ & $\begin{array}{l}\text { Websites provide users with total prices of goods and installments for } \\
\text { consumers' decision-making of purchases. }\end{array}$ \\
\hline & 3. Product ranking $(\mathrm{PR})$ & $\begin{array}{l}\text { Users can easily search for popular products or hot goods on the websites. } \\
\text { When purchasing goods, they have clear information, and it saves time. }\end{array}$ \\
\hline & $\begin{array}{l}\text { 4. Display of virtual } \\
\text { reality (DVR) }\end{array}$ & $\begin{array}{l}\text { Using virtual reality, products are displayed, and customers can even use } \\
\text { the products. }\end{array}$ \\
\hline & $\begin{array}{l}\text { 5. Suggestions on new } \\
\text { products (SNP) }\end{array}$ & Ask customers to offer suggestions on new products. \\
\hline
\end{tabular}


Table 2. Cont.

\begin{tabular}{|c|c|c|}
\hline \multicolumn{2}{|c|}{ Interactive Functions } & Descriptions \\
\hline \multirow{5}{*}{$\begin{array}{l}\text { Service } \\
\text { (SV) }\end{array}$} & 1. Customer database (CD) & $\begin{array}{l}\text { Members' personal basic information, such as birthdays, telephone } \\
\text { numbers, identity and address are stored in a database for goods delivery, } \\
\text { mailing of catalogues, and e-paper. }\end{array}$ \\
\hline & $\begin{array}{l}\text { 2. Reservation of } \\
\text { e-paper (REP) }\end{array}$ & $\begin{array}{l}\text { Websites actively send e-paper to users regarding new products, prices, } \\
\text { or activities. Hence, consumers can absorb the information and have } \\
\text { more choices. }\end{array}$ \\
\hline & 3. Shopping cart (SC) & $\begin{array}{l}\text { Consumers immediately find the shopping list and goods and have a } \\
\text { convenient purchase process. }\end{array}$ \\
\hline & $\begin{array}{l}\text { 4. Customized } \\
\text { promotion }(\mathrm{CP})\end{array}$ & $\begin{array}{l}\text { According to consumers' different needs, the websites recommend } \\
\text { suitable products. }\end{array}$ \\
\hline & $\begin{array}{l}\text { 5. Online problem } \\
\text { diagnosis (OPD) }\end{array}$ & $\begin{array}{l}\text { Ask customers to ask questions online, and answers are provided to } \\
\text { solve problems. }\end{array}$ \\
\hline \multirow{5}{*}{$\begin{array}{l}\text { Interactive } \\
\text { (ITR) }\end{array}$} & 1. E-mail (EM) & $\begin{array}{l}\text { When customers have any questions or need assistance, they can } \\
\text { use e-mail. }\end{array}$ \\
\hline & 2. Message board (MB) & $\begin{array}{l}\text { After purchasing goods, consumers can contact the firms online without } \\
\text { missing the messages. In addition, they can freely express their opinions } \\
\text { on various subjects. }\end{array}$ \\
\hline & $\begin{array}{l}\text { 3. Online users' forum } \\
\text { (OUF) }\end{array}$ & $\begin{array}{l}\text { Users recommend or comment on the products after purchasing goods to } \\
\text { allow other users to know the characteristics of goods. Professional } \\
\text { managers will be responsible for the responses. }\end{array}$ \\
\hline & $\begin{array}{l}\text { 4. Online questionnaire } \\
\text { (OQ) }\end{array}$ & $\begin{array}{l}\text { Users fill in a questionnaire to provide their information and needs. } \\
\text { Decision makers can obtain information to respond to customers. }\end{array}$ \\
\hline & 5. E-cards (EC) & Sending e-cards to customers on various holidays. \\
\hline \multirow{5}{*}{$\begin{array}{l}\text { Promotion } \\
\text { (PRM) }\end{array}$} & 1. Advertising (AD) & $\begin{array}{l}\text { They expose the products and enhance their reputation to make more } \\
\text { people to know the products and increase potential consumers. } \\
\text { Advertising is usually presented on TV and websites. }\end{array}$ \\
\hline & 2. Lottery/prices $(\mathrm{L} / \mathrm{P})$ & $\begin{array}{l}\text { Shopping websites attract the visitors by prizes or lotteries. The activities } \\
\text { promote he corporate image or products to consumers. }\end{array}$ \\
\hline & 3. Coupons (CPN) & Websites provide coupons and attract consumers by discounts. \\
\hline & 4. Media promotion (MP) & Customers can receive information regularly. \\
\hline & 5. Online games $(\mathrm{OG})$ & Users can play online games. \\
\hline
\end{tabular}

\subsection{Analytic Network Process (ANP)}

An analytic hierarchy process (AHP) proposed by Saaty in 1980 can address complicated problems. The basic assumption of an AHP is that parts or clusters at each hierarchy are independent. However, many real decision-making issues cannot be constructed hierarchically because they usually include effects among criteria or dependency among high and low level elements. In addition, the construction of a practical model should be based on feedback in clusters [38,39]. Saaty proposed ANP in 1996, and it was mainly applied to interdependence among plans or criteria. Steps of an ANP in decision-making analysis are shown as follows [40,41].

\subsubsection{Construction of Problem Structure}

According to problem characteristics, it confirms the goals, finds decision-making criteria and sub-criteria of the clusters, and recognizes the interdependence among the criteria. The interdependence is outer dependence. When sub-criteria of the clusters influence each other, it is inner dependence. Thus, the total structure of decision-making problems is drawn.

\subsubsection{Pair Comparison of Decision-Making Criteria}

Pair comparison means to compare the pair criteria, which includes two parts-including pair comparison of criteria and comparison of sub-criteria in clusters. Pair comparison of sub-criteria is 
classified into pair comparison in the same clusters and different clusters. Relative important values are based on the 1-9 scale of Saaty. The following formula for the $A_{k}$ pairwise comparison matrix was developed after pairwise comparison of factors of $n$ units Equation (1):

$$
A_{k}=\left[a_{i j}\right]_{n \times n}=\left[\begin{array}{cccc}
a_{11} & a_{12} & \cdots & a_{1 n} \\
a_{21} & a_{22} & \cdots & a_{2 n} \\
\vdots & \vdots & \ddots & \vdots \\
a_{n 1} & a_{n 2} & \cdots & a_{n n}
\end{array}\right]=\left[\begin{array}{cccc}
\frac{w_{1}}{w_{1}} & \frac{w_{1}}{w_{2}} & \cdots & \frac{w_{1}}{w_{n}} \\
\frac{w_{2}}{w_{1}} & \frac{w_{2}}{w_{2}} & \cdots & \frac{w_{2}}{w_{n}} \\
\vdots & \vdots & \ddots & \vdots \\
\frac{w_{n}}{w_{1}} & \frac{w_{n}}{w_{2}} & \cdots & \frac{w_{n}}{w_{n}}
\end{array}\right]_{n \times n}
$$

in which

$A_{k}, k=1,2, \ldots, K$; refers to the $\mathrm{K}_{\text {th }}$ pairwise comparison matrix

$W_{i}, i j=1,2, \ldots, n$; indicates the importance of factor $i$ as evaluated by experts

$a_{i i}=1, i=1,2, \ldots, n$; stands for the pairwise comparisons between factor $i$ and itself

$\mathrm{a}_{i j}=1 / \mathrm{a}_{j i}, \mathrm{a}_{i j}=\mathrm{w}_{i} / \mathrm{w}_{j}, i, j=1,2, \ldots, \mathrm{n}$; refers to the extent of importance of factor $i$ as opposed to factor $j$

An ANP pair comparison shows the matrix framework and original priority vector to evaluate and compare the importance of relative relationships among elements or the matrix. The formula is shown in Equation (2):

$$
\lambda_{\max }=\frac{\sum_{i=1}^{n}(A W)_{i}}{W_{i} \times n}, i=1,2, \ldots, n
$$

in which $\lambda_{\max }$ refers to the maximum eigenvalue of the $A_{k}$ pairwise comparison matrix.

Finally, according to the respondents' questionnaire results, the researcher tests the reasonability of weight distribution and adopts the C.R. (consistency ratio) as the criterion of judgment, as shown in Equation (3). When the C.R. is lower than 0.1, consistency is acceptable; otherwise, the matrices of the level should be adjusted to result in satisfying consistency of the total ranking.

$$
\text { C.R. }=\text { C.I./R.I. }
$$

where C.I. is the consistency index and R.I. is the random inconsistency.

\subsubsection{Formation of Super Matrix and Selection of Plans}

Since ANP is a group decision-making method based on the integration of numerous experts' opinions, Saaty proposed to take the geometric means of individual experts' evaluations as the grounds for the subsequently developed super matrix [42]. The super matrix consists of several sub-matrices. Each sub-matrix includes the interaction of the clusters and a pair comparison is conducted with elements in other clusters. The weight of each sub-matrix is obtained by eigenvector through pair comparison and finally forms the super matrix. Cultivation of an ANP includes three matrices. The unweighted super matrix is obtained by original pair comparison; the weighted super matrix means weight of the same factor in the unweighted matrix multiplied with related cluster weights. Hence, the total of vertical fields is one. The limit super matrix means multiplication of the weighted matrix with multiple powers until convergence. Numbers of fields are the same, as shown in Equation (4):

$$
W_{\lim }=\lim _{k \rightarrow \infty}\left(W_{\text {weighted }}\right)^{k}
$$

Based on multiple operations of the super matrix, the weights obtained mean the ranking suggested by the plans after matrix calculation. The plan with the highest weights is the result of the ANP, and it is the best plan for the decision-makers. 
Based on the above, when there are different plans of multi-objectives, multi-criteria, and multi-behavior decision-making, an ANP provides a highly compatible framework and ranking of the plans for decision-makers to select the best [43-47]. In addition, it can be applied to the analysis of importance of performance indicators of enterprises as the criteria of strategy execution and resource distribution [48-50]. Therefore, this study attempts to explore the importance of website design indicators for e-entrepreneurship in relation to the internal environment (the status quo of the company) and the external environment (industrial trend) from the perspective of an ANP. The implications of such indicators are also of interest. Thus, by the analytical result of an ANP, this study tries to recognize the importance of the website design indicators of e-entrepreneurship and probe into the content as the important reference for strategic management and resource distribution of enterprises. In addition, because this study focuses on application of ANP evaluation results, the precise analytical process of an ANP is not discussed, and the research only shows the figures of evaluation results.

\section{Research Design}

The case company was established in 1988. It is a manufacturer as well as a distributor of electronic products in Taiwan. It owns physical stores selling products ranging from computers and telecommunication products to domestic electronic appliances. The CEO of the case company noticed the prosperous development of e-commerce, so the company intended to rely on the internet to boost competitiveness and increase profits [20]. Therefore, the company decided to launch its e-entrepreneurship initiative to establish online stores and attract potential online shoppers.

This study formed a project team with the case company and planned an interactive website design for e-entrepreneurship. This research applied an ANP to the analysis and evaluation of interactive website design indicators and took into account the perspectives of the internal environment (the status quo of the company) and the external environment (the industrial trend). By applying the model of ANP and the perspectives of the internal and external environment, this study analyzes interactive website design indicators to confirm the importance of design indicators as the key points to design to match the requirements of e-Entrepreneurship. The process is shown in Table 3 and Figure 1 as follows.

Table 3. The main steps of the evaluation process.

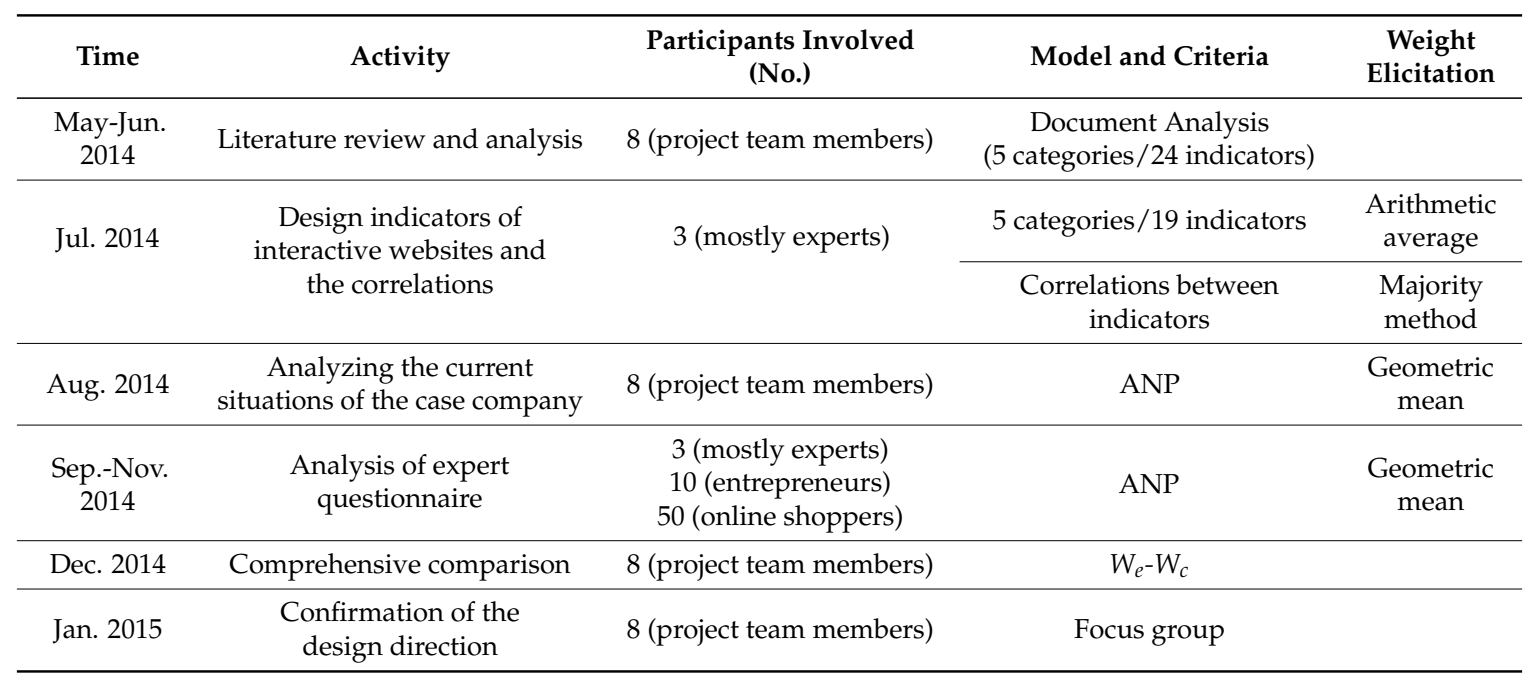




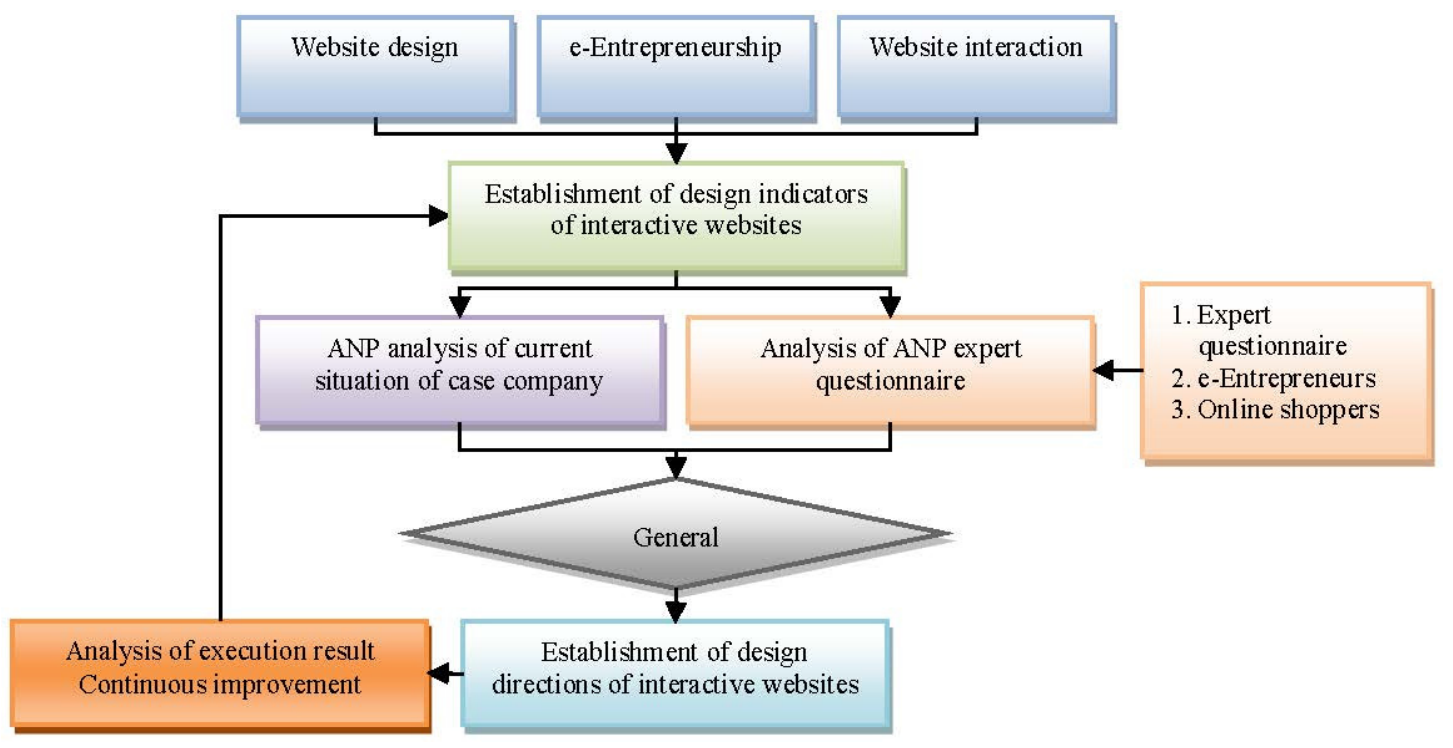

Figure 1. Research design process.

(1) Literature review and analysis.

A group of eight people, including some of the authors and the managers of the case company, searched for relevant literature, as a response to the external industrial changes, for further discussion and analysis.

(2) The initially-established design indictors of interactive websites were used as the basis for the development of an expert questionnaire.

The indicators in the questionnaire were evaluated by three experts specializing in website design to select important design indicators of interactive websites and to identify the correlations between them. The results were further employed as the basis for the design of the ANP self-appraisal questionnaire and the ANP expert questionnaire.

(3) ANP analysis of the current situation of the case company.

Project team members conducted the ANP self-report questionnaire survey on interactive website design indicators. By evaluation of the interactive website design indicators, the weight distribution of the design indicators was studied to find the current policy and execution of the case company.

(4) The analysis of the ANP expert questionnaire.

At this stage, three experts specializing in e-entrepreneurship were invited to join the research group to conduct the ANP expert questionnaire survey and evaluate the design indicators of interactive websites. Moreover, 10 entrepreneurs and 50 online shoppers were asked to participate in the ANP questionnaire survey. The results derived from the ANP surveys given to the above three groups of participants were integrated to enhance the reliability of the final findings.

(5) Comprehensive comparison.

This study, from the perspectives of the internal (the status quo of the company) and external environment (the industrial trend), compared the analysis of company status and that of expert opinions synthetically. Through the comparison, the differences between the results derived from the two types of analyses were found to identify the essential design indicators. 
(6) Confirmation of design direction.

According to comprehensive comparison, we can clearly recognize the gap between the current situation of the firm and experts' opinions, which is used to confirm key design indicators. Based on the analytical results, limited corporate resources are re-distributed, goals and plans are established and execution and analysis are precisely controlled as the reference for future improvement.

\section{Results and Discussion}

In this section, we will analyze the current situation of the case company, the expert questionnaire, and compare analytical results.

\subsection{Design Indicators of an Interactive Website and the Correlations}

As a response to the trends of e-commerce, a project team with eight members was formed to carry out a relevant literature review for a series of discussions and analysis of design indicators for interactive websites. They were divided into five categories, including a total of 24 design indicators based on which an expert questionnaire was developed, and evaluated by three website design experts to identify important design indicators of interactive websites and the correlations. The three experts ranked the salience of the 24 indicators from 0 to 10 . The average values were rounded to the second decimal place (as shown in Table 4). The first quartile of the average values was used $(Q 1=7.33)$ to determine which indicators were sufficiently adequate as important design indicators of interactive websites. A total of 19 indicators were selected and categorized into five categories; namely, 1. Design (DS), 2. Checking (CK), 3. Service (SV), 4. Interactive (ITR), and 5. Promotion (PRM).

Table 4. Expert evaluations on design indicators of interactive websites.

\begin{tabular}{lcc}
\hline \multicolumn{1}{c}{ Design Indicators } & Average Value & Remark \\
\hline 1-1 Webpage announcement (WA) & 8.76 & retain \\
1-2 Simple operation of interface (SOI) & 7.79 & retain \\
1-3 Website browsing (WB) & 7.73 & retain \\
1-4 Opinion survey on websites (OSW) & 6.68 & delete \\
2-1 Product searching (PS) & 8.79 & retain \\
2-2 Price checking (PC) & 8.76 & retain \\
2-3 Product ranking (PR) & 7.86 & retain \\
2-4 Display of virtual reality (DVR) & 7.79 & retain \\
2-5 Suggestions on new products (SNP) & 7.06 & delete \\
3-1 Customer database (CD) & 8.75 & retain \\
3-2 Reservation of e-paper (REP) & 7.78 & retain \\
3-3 Shopping cart (SC) & 8.82 & retain \\
3-4 Customized promotion (CP) & 8.73 & retain \\
3-5 Online problem diagnosis (OPD) & 6.71 & delete \\
4-1 E-mail (EM) & 8.76 & retain \\
4-2 Message board (MB) & 8.79 & retain \\
4-3 Online users' forum (OUF) & 7.76 & retain \\
4-4 Online questionnaire (OQ) & 7.33 & retain \\
4-5 E-cards (EC) & 6.66 & delete \\
5-1 Advertising (AD) & 8.86 & retain \\
5-2 Lottery/prices (L/P) & 7.73 & retain \\
5-3 Coupons (CPN) & 7.33 & retain \\
5-4 Media promotion (MP) & 7.86 & retain \\
5-5 Online games (OG) & 6.33 & delete \\
\hline
\end{tabular}

The three experts were asked to note the correlations between indicators. The validity of the results was determined if more than two experts shared the same opinions (as shown in Table 5 and Figure 2). The final outcomes formed the basis for the design of the ANP self-appraisal questionnaire and ANP expert questionnaire. 
Table 5. Correlations of design indicators of interactive websites.

\begin{tabular}{|c|c|c|c|c|c|c|c|c|c|c|c|c|c|c|c|c|c|c|c|}
\hline Design Indicators & WA & SOI & WB & PS & PC & PR & DVR & $\mathrm{CD}$ & REP & $\mathrm{SC}$ & $\mathrm{CP}$ & EM & MB & OUF & OQ & AD & $\mathrm{L} / \mathrm{P}$ & CPN & MP \\
\hline Webpage announcement (WA) & & & $\mathrm{V}$ & & & & & & & & & $\mathrm{V}$ & & & & $\mathrm{V}$ & $\mathrm{V}$ & $\mathrm{V}$ & \\
\hline Simple operation of interface (SOI) & & & $\mathrm{V}$ & & & & $\mathrm{V}$ & & & $\mathrm{V}$ & $\mathrm{V}$ & & & & & & & & \\
\hline Website browsing (WB) & & $\mathrm{V}$ & & & & & & & & & & & & & $\mathrm{V}$ & & & & \\
\hline Product searching (PS) & & $\mathrm{V}$ & & & $\mathrm{V}$ & $\mathrm{V}$ & & & & $\mathrm{V}$ & $\mathrm{V}$ & $\mathrm{V}$ & $\mathrm{V}$ & & $\mathrm{V}$ & & & & \\
\hline Price checking (PC) & & $\mathrm{V}$ & & $\mathrm{V}$ & & $\mathrm{V}$ & $\mathrm{V}$ & & & $\mathrm{V}$ & $\mathrm{V}$ & $\mathrm{V}$ & $\mathrm{V}$ & $\mathrm{V}$ & $\mathrm{V}$ & & & & \\
\hline Product ranking (PR) & $\mathrm{V}$ & & & $\mathrm{V}$ & $\mathrm{V}$ & & & & $\mathrm{V}$ & & & & $\mathrm{V}$ & $\mathrm{V}$ & $\mathrm{V}$ & $\mathrm{V}$ & $\mathrm{V}$ & $\mathrm{V}$ & $\mathrm{V}$ \\
\hline Display of virtual reality (DVR) & $\mathrm{V}$ & & & $\mathrm{V}$ & & & & & & & & & & & & & & & \\
\hline Customer database (CD) & & & $\mathrm{V}$ & & & & & & $\mathrm{V}$ & $\mathrm{V}$ & $\mathrm{V}$ & $\mathrm{V}$ & $\mathrm{V}$ & $\mathrm{V}$ & $\mathrm{V}$ & & $\mathrm{V}$ & $\mathrm{V}$ & $\mathrm{V}$ \\
\hline Shopping cart (SC) & & & & $\mathrm{V}$ & $\mathrm{V}$ & & & V & & & $\mathrm{V}$ & & & & & & & & \\
\hline Customized promotion (CP) & $\mathrm{V}$ & $\mathrm{V}$ & V & $\mathrm{V}$ & $\mathrm{V}$ & & $\mathrm{V}$ & $\mathrm{V}$ & $\mathrm{V}$ & $\mathrm{V}$ & & $\mathrm{V}$ & & & $\mathrm{V}$ & $\mathrm{V}$ & $\mathrm{V}$ & $\mathrm{V}$ & $\mathrm{V}$ \\
\hline E-mail (EM) & & & & & & & & $\mathrm{V}$ & $\mathrm{V}$ & & & & $\mathrm{V}$ & $\mathrm{V}$ & $\mathrm{V}$ & & $\mathrm{V}$ & $\mathrm{V}$ & \\
\hline Message board (MB) & & $\mathrm{V}$ & & & & & & & & & & $\mathrm{V}$ & & $\mathrm{V}$ & $\mathrm{V}$ & & & & \\
\hline Online users' forum (OUF) & & & & $\mathrm{V}$ & $\mathrm{V}$ & $\mathrm{V}$ & & & & $\mathrm{V}$ & $\mathrm{V}$ & $\mathrm{V}$ & V & & $\mathrm{V}$ & & & & \\
\hline Online questionnaire (OQ) & & & & & & & $\mathrm{V}$ & $\mathrm{V}$ & & & $\mathrm{V}$ & $\mathrm{V}$ & $\mathrm{V}$ & $\mathrm{V}$ & & $\mathrm{V}$ & & $\mathrm{V}$ & \\
\hline Advertising (AD) & $\mathrm{V}$ & & & $\mathrm{V}$ & $\mathrm{V}$ & $\mathrm{V}$ & & & $\mathrm{V}$ & & & & & & $\mathrm{V}$ & & $\mathrm{V}$ & $\mathrm{V}$ & $\mathrm{V}$ \\
\hline Lottery/ prices $(\mathrm{L} / \mathrm{P})$ & $\mathrm{V}$ & & & & & & V & & $\mathrm{V}$ & & & $\mathrm{V}$ & V & $\mathrm{V}$ & & $\mathrm{V}$ & & $\mathrm{V}$ & \\
\hline Coupons $(\mathrm{CPN})$ & & & & & $\mathrm{V}$ & $\mathrm{V}$ & & $\mathrm{V}$ & & $\mathrm{V}$ & $\mathrm{V}$ & $\mathrm{V}$ & & $\mathrm{V}$ & & $\mathrm{V}$ & $\mathrm{V}$ & & \\
\hline
\end{tabular}




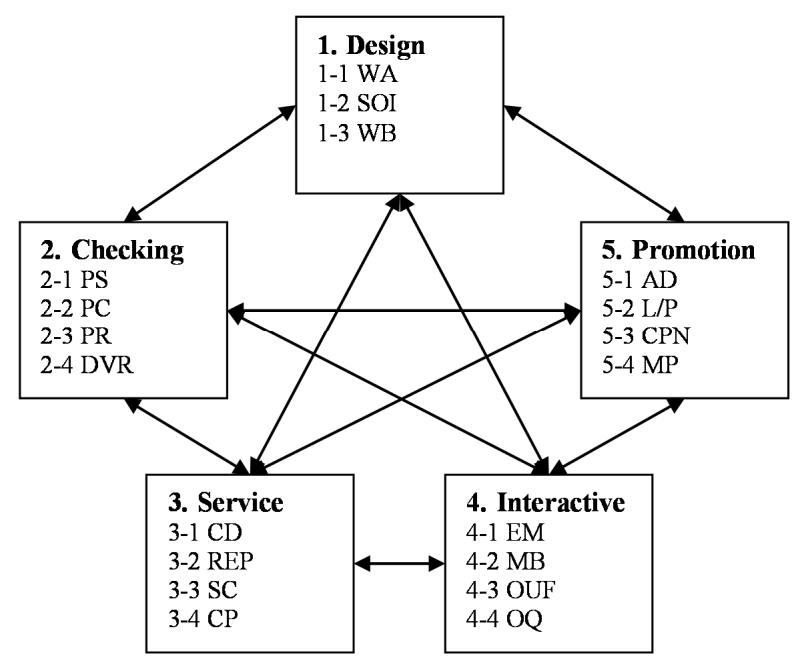

Figure 2. Correlations of ANP design indicators of interactive websites.

\subsection{ANP Analysis of the Current Situation of the Case Company}

To recognize the importance of interactive website design indicators in the current execution of the case company by ANP, this study obtains the relative weights of 19 design indicators. According to current corporate operations, a project team compares interdependence of pair indicators. Using Super Decision (Pittsburgh, PA, USA), this study conducts an ANP and obtains two super matrices, an unweighted matrix and a weighted matrix, as shown in Tables A1 and A2. The ranking of the relative weights of the interactive website design indicators is shown in Table 6. When the weight (Wc) is higher, it means the indicator is more important for the case company. The top five weights of design indicators are "customized promotion" (0.183), "customer database" (0.126), "online questionnaire" (0.073), "simple operation of interface" (0.065), and "product ranking" (0.061).

Based on the above, regarding website design, the case company focuses on collection of customer data by online questionnaires and proper management and analysis of the database. By understanding customers' needs and sales of products, a human interface is provided, resulting in customized service quality. Therefore, we can clearly recognize the current corporate operations policy and design direction of the case company's website.

\subsection{ANP Analysis of Expert Questionnaire}

To determine the importance of interactive website design indicators for experts, by ANP, this study obtains the relative weighs of 19 design indicators. In terms of the analysis of expert opinions, three experts specializing in e-entrepreneurship, 10 e-Entrepreneurs and 50 online shoppers were initially invited to compare the correlations of pairs of the design indicators in accordance with key factors of successful e-entrepreneurship. As a consequence, three experts specialized in e-entrepreneurship, eight e-entrepreneurs and 42 online shoppers completed the questionnaire. To prevent the three e-entrepreneurs' opinions from being underestimated, this study calculated the geometric means of the survey results derived from the eight e-entrepreneurs and 42 online shoppers and converted them into one set of e-entrepreneur data and one set of online-shopper data. A total of five sets of survey results (including the three sets of survey data derived from the experts) were further integrated into ANP expert opinions using the super matrix. Using Super Decision, the researcher calculates by ANP and acquires two super matrices: an unweighted matrix and a weighted matrix, as shown in Tables A3 and A4. The ranking of relative weights of interactive website design indicators is shown in the experts' opinions of Table 6. When the weight (We) is higher, it means it is more important for most of experts. The top five are "product searching" (0.175), "price checking" $(0.150)$, "product ranking" (0.110), "customized promotion" (0.098) and "advertising" (0.065). 
Table 6. ANP analysis

\begin{tabular}{|c|c|c|c|c|c|c|c|}
\hline & \multirow{2}{*}{ Items of Evaluation } & \multicolumn{2}{|c|}{ Evaluation of Current Situation } & \multicolumn{2}{|c|}{ Experts' Opinions } & \multicolumn{2}{|c|}{ Comprehensive Comparison } \\
\hline & & Weight $\left(W_{c}\right)$ & Ranking & Weight $\left(W_{e}\right)$ & Ranking & $\operatorname{Gap}\left(W_{e}-W_{c}\right)$ & Ranking \\
\hline \multirow{3}{*}{ Design } & Webpage announcement (WA) & 0.048 & 7 & 0.034 & 12 & -0.014 & 13 \\
\hline & Simple operation of interface (SOI) & 0.065 & 4 & 0.055 & 6 & -0.010 & 11 \\
\hline & Website browsing (WB) & 0.029 & 16 & 0.021 & 14 & -0.008 & 9 \\
\hline \multirow{4}{*}{ Checking } & Product searching (PS) & 0.037 & 14 & 0.175 & 1 & 0.138 & 1 \\
\hline & Price checking (PC) & 0.037 & 13 & 0.150 & 2 & 0.112 & 2 \\
\hline & Product ranking (PR) & 0.061 & 5 & 0.110 & 3 & 0.050 & 3 \\
\hline & Display of virtual reality (DVR) & 0.009 & 19 & 0.043 & 9 & 0.035 & 4 \\
\hline \multirow{4}{*}{ Service } & Customer database (CD) & 0.126 & 2 & 0.048 & 7 & -0.078 & 18 \\
\hline & Reservation of e-paper (REP) & 0.038 & 12 & 0.042 & 10 & 0.004 & 6 \\
\hline & Shopping cart (SC) & 0.041 & 11 & 0.030 & 13 & -0.011 & 12 \\
\hline & Customized promotion (CP) & 0.183 & 1 & 0.098 & 4 & -0.085 & 19 \\
\hline \multirow{4}{*}{ Interactive } & E-mail (EM) & 0.042 & 10 & 0.009 & 16 & -0.033 & 16 \\
\hline & Message board (MB) & 0.017 & 17 & 0.008 & 18 & -0.009 & 10 \\
\hline & Online users' forum (OUF) & 0.047 & 9 & 0.043 & 8 & -0.004 & 7 \\
\hline & Online questionnaire (OQ) & 0.073 & 3 & 0.018 & 15 & -0.055 & 17 \\
\hline \multirow{4}{*}{ Promotion } & Advertising (AD) & 0.048 & 8 & 0.065 & 5 & 0.018 & 5 \\
\hline & Lottery/prices (L/P) & 0.032 & 15 & 0.008 & 17 & -0.023 & 15 \\
\hline & Coupons (CPN) & 0.058 & 6 & 0.038 & 11 & -0.020 & 14 \\
\hline & Media promotion (MP) & 0.011 & 18 & 0.005 & 19 & -0.006 & 8 \\
\hline
\end{tabular}


Based on the above, regarding interactive website design of e-entrepreneurship, the experts suggest the importance of product information checking and providing customers with more complete and a convenient shopping environment. Unlike physical stores with clerks who explain and introduce products to customers, online stores must rely on advertising to inform customers of new products, popular goods, and even ranking of goods. Based on customers' special needs, they offer customized service and promotion to increase online customers and sales. Therefore, we can confirm the future direction of interactive website design for e-entrepreneurship and set up execution strategies for the case company.

\subsection{Comprehensive Comparison and Analysis}

Regarding the ANP results of Sections 4.2 and 4.3 this study compares the weights of interactive website design indicators. The criteria are set up for future strategy execution according to the gap of the importance in the evaluation of the design indicators between the current situation of the company and the experts' opinions. As shown in Figure 3, by including the trend line in the bar diagram of weights, we can show that, at the current stage, the case company must be improved. Significant execution effectiveness refers to key design indicators. A real trend line means the importance of certain design indicators for most of the experts, and the degree is higher than the current situation of the case company. A dotted trend line means the importance of certain design indicators for most of experts is lower than the current situation of the case company.

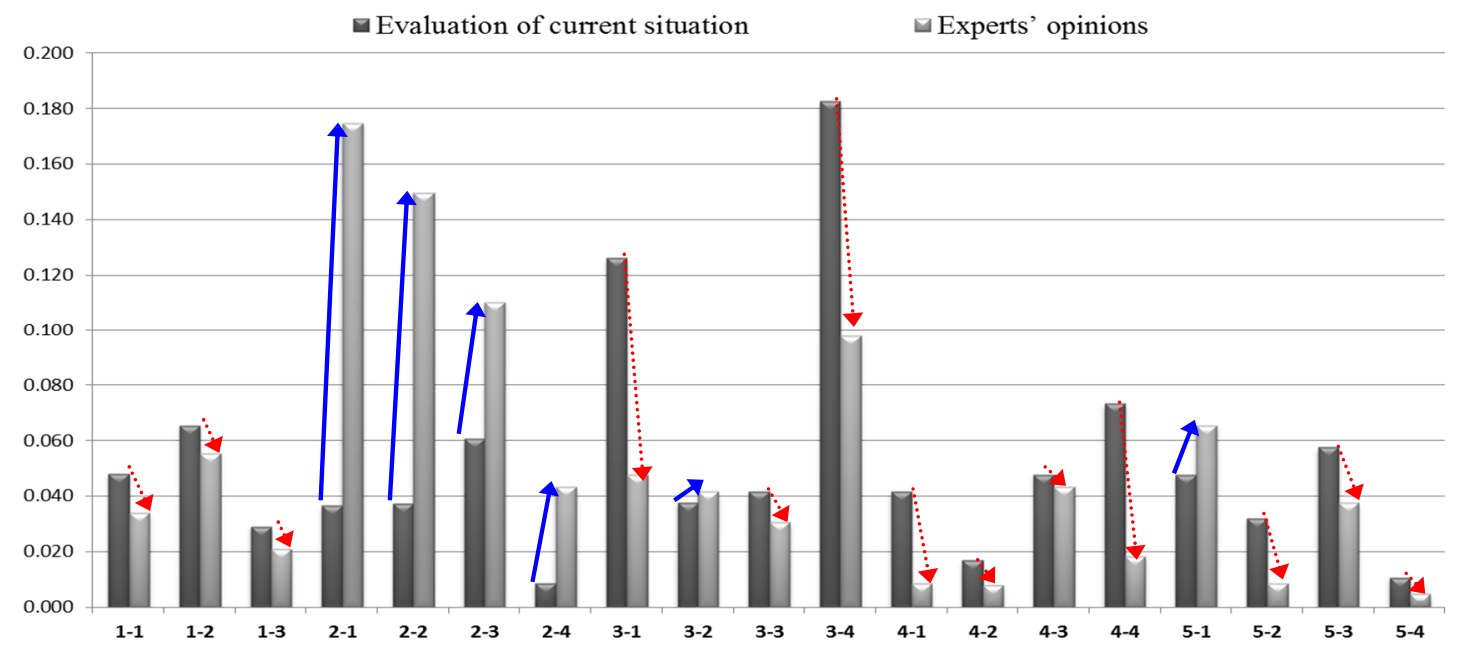

Figure 3. Comprehensive comparison of current situation of company and experts' suggestions.

The results demonstrate that the design indicators of real trend lines are "product searching" (0.138), "price checking" (0.112), "product ranking" (0.050), "display of virtual reality" (0.035), "advertising" (0.018), and "reservation of e-paper" (0.004). These are defined as "key design indicators". This shows that for future operations of the company, the design indicators must be reinforced, and the execution is more effective than for the other design indicators. In addition, the rest of the design indicators refer to dotted trend lines. This means that the case company currently focuses on the development of the design indicators. However, for future operations of the company, we suggest slightly turning the resources invested in indicators to other "key design indicators." In addition, according to the comprehensive comparison in Table 6, we recognize the gap (We-Wc) between the case company and the experts regarding interactive website design. Notably, the "display of virtual reality" is a new interactive technique of online stores. Although it is ninth in the current ranking of experts, the case company does not pay attention to the indicator, and the ranking is last (19th). After comprehensive comparison, the indicator is upgraded to the top four. This means that if the case company invests resources in the design indicator, the execution will be more effective than for other 
design indicators. On the contrary, "Customized promotion" is in the top four in the ranking of experts. However, because the case company values this indicator, it is first in the ranking. This demonstrates that the technique of the design indicator for the case company should be mature. By comprehensive comparison, the indicator is last in the ranking. Hence, if the case company invests the resources in this design indicator, execution will be less effective than for the other design indicators. We suggest developing the other key design indicators.

Based on the above, by comprehensive comparison, we realize the gap of the importance of design indicators in the current situation of the company and the experts' opinions and further confirm key design indicators with higher execution effectiveness. Thus, we can set up a future operational strategy and effectively utilize the limited resources.

\section{Conclusions}

The following suggestions are proposed.

\subsection{Conclusion and Managerial Implications}

This study treats the ANP as an analytical tool for strategy planning and constructs an ANP assessment model of interactive website design indicators. By research analysis and discussion of the case company, we develop conclusions and managerial implications as follows:

(1) According to the characteristics of the ANP, this study constructs a network system with a specific structure. Interactive website design indicators of e-entrepreneurship are generalized as (1) Design; (2) Checking; (3) Service; (4) Interactive; and (5) Promotion, including 19 design indicators. At the planning stage, the decision-making team can include different indicators to systematize the complicated issues.

(2) By analyzing the current situation of the case company through the ANP, this study recognizes current website design points. This is based on customer service and data analysis. The top five are customized promotion, customer database, online questionnaire, simple operation of interface, and product ranking. They serve as a reference for the case company to plan strategies.

(3) By analyzing the expert questionnaire through the ANP, we can respond to the key success factors of e-entrepreneurship and confirm the key points of interactive website design. This emphasizes the interaction between websites and customers and message transmission. According to the customers' special needs, customized service and promotion are provided. The top five are product searching, price checking, product ranking, customized promotion, and advertising. Thus, we confirm the future website design direction of e-entrepreneurship for the case company.

(4) According to the analytical results of Sections 4.1 and 4.2 as to interactive website design indicators, there is a significant gap between the current importance for the case company and the experts' suggestions. This demonstrates that in response to market changes, the execution strategy of the case company must be properly adjusted. However, does this mean to invest in all resources according to experts' opinions? Based on the case study, it is necessary to develop a comprehensive comparison. Hence, we confirm that the key design indicators are product searching, price checking, product ranking, display of virtual reality, advertising, and reservation of e-papers. In online stores, customers cannot touch the products. Firms should try to more easily and authentically present products using multimedia data presentation techniques. 
(5) By the validation of key design indicators, this study recognizes the urgent factors that should be enhanced by the case company. Therefore, the managerial implication is as follows. With the vigorous development of the internet, consumers' consumption behavior, as well as business and trading models, are changed. This study designs an ANP assessment model of interactive website design indicators. Thus, the case company changes from questioning to understanding the points for improvement. We suggest that for small and medium enterprises, website design companies and those who are interested in e-entrepreneurship can plan an interactive website design according to the findings of this study. They can even self-report using an ANP comprehensive assessment model to effectively lower the scope of strategy planning and focus on the construction of effective strategies. Thus, business decision-makers can make the right decisions, enhance effectiveness of corporate strategies and strengthen competitiveness.

\subsection{Suggestions}

Given the findings and limitations of this study, we have a number of suggestions for $3 \mathrm{C}$ product distributors, e-entrepreneurs, and future research.

\subsubsection{C Product Distributors}

In this study, a case study was conducted for a $3 C$ product distributor, so the results regarding the design indicators of interactive websites can be a useful reference for companies in the same industry, especially when they intend to enter the e-market or launch e-entrepreneurship.

\subsubsection{For e-Entrepreneurs}

This study highlighted "interaction" as the key guideline for the design of websites and established an ANP evaluation model of design indicators of interactive websites. The model can help companies of different kinds identify or determine the design indicators that fit their needs. It is advised that e-entrepreneurs design interactive websites with characteristics defined in line with the ANP evaluative model. The status quo or characteristics of the companies should also be taken into account.

\subsubsection{For Future Research}

The global digital era is a worldwide trend, in which products are promoted and sold via the internet. Hence, it is essential to generate a website that enables mutual interaction with target customers if an e-commerce enterprise aims to keep track of customers' preferences. Therefore, it is advised to apply the model of interactive website design indicators to different sectors to analyze a company's internal current status and the trend in the outer world as the preparation of effective introduction of e-entrepreneurship. Furthermore, even though this study mainly focuses on the design of interactive websites, it is also worthwhile to consider the security of the website to enhance the customers' confidence in online shopping mechanisms. For future research it is, therefore, suggested to take into account the relevant security issues into the evaluation model for website design for the purpose of constructing an online shopping platform satisfying the customers' needs. The final future research suggestion is to invite customers to express their degree of satisfaction and to conduct customer need analysis to help e-entrepreneurs develop promising business strategies.

Author Contributions: Shi-Jer Lou and Li-Chung Chao conceived and designed the experiments; Chih-Chao Chung and Shi-Jer Lou performed the experiments; Chih-Chao Chung and Chin-Hui Chen analyzed the data; Chih-Chao Chung and Li-Chung Chao contributed reagents / materials / analysis tools; Chih-Chao Chung and Chin-Hui Chen wrote the paper.

Conflicts of Interest: The authors declare no conflict of interest. 


\section{Appendix A}

Table A1. Unweighted super matrix of analysis on the current situation of the company.

\begin{tabular}{|c|c|c|c|c|c|c|c|c|c|c|c|c|c|c|c|c|c|c|c|}
\hline \multirow{2}{*}{\begin{tabular}{|c|} 
Categories \\
Design indicators
\end{tabular}} & \multicolumn{3}{|c|}{ Design } & \multicolumn{4}{|c|}{ Checking } & \multicolumn{4}{|c|}{ Service } & \multicolumn{4}{|c|}{ Interactive } & \multicolumn{4}{|c|}{ Promotion } \\
\hline & WA & SOI & WB & PS & PC & PR & DVR & $\mathrm{CD}$ & REP & SC & $\mathrm{CP}$ & EM & MB & OUF & OQ & $\mathrm{AD}$ & $\mathrm{L} / \mathrm{P}$ & $\mathrm{CPN}$ & MP \\
\hline Webpage announcement (WA) & 0 & 0 & 0.25 & 0 & 0 & 0 & 0 & 0 & 0 & 0 & 0 & 1 & 0 & 0 & 0 & 1 & 1 & 1 & 0 \\
\hline Simple operation of interface (SOI) & 0 & 0 & 0.75 & 0 & 0 & 0 & 1 & 0 & 0 & 1 & 1 & 0 & 0 & 0 & 0 & 0 & 0 & 0 & 0 \\
\hline Website browsing (WB) & 0 & 1 & 0 & 0 & 0 & 0 & 0 & 0 & 0 & 0 & 0 & 0 & 0 & 0 & 1 & 0 & 0 & 0 & 0 \\
\hline Product searching (PS) & 0 & 0.8 & 0 & 0 & 0.25 & 0.25 & 0 & 0 & 0 & 0.333 & 0.75 & 0.667 & 0.163 & 0 & 0.168 & 0 & 0 & 0 & 0 \\
\hline Price checking (PC) & 0 & 0.2 & 0 & 0.163 & 0 & 0.75 & 1 & 0 & 0 & 0.667 & 0.25 & 0.333 & 0.297 & 0.2 & 0.349 & 0 & 0 & 0 & 0 \\
\hline Product ranking (PR) & 0.667 & 0 & 0 & 0.297 & 0.75 & 0 & 0 & 0 & 1 & 0 & 0 & 0 & 0.540 & 0.8 & 0.484 & 1 & 1 & 1 & 0 \\
\hline Display of virtual reality (DVR) & 0.333 & 0 & 0 & 0.540 & 0 & 0 & 0 & 0 & 0 & 0 & 0 & 0 & 0 & 0 & 0 & 0 & 0 & 0 & 0 \\
\hline Customer database (CD) & 0 & 0 & 0.25 & 0 & 0 & 0 & 0 & 0 & 0.667 & 0.540 & 0.75 & 0.25 & 1 & 1 & 0.594 & 0 & 0.333 & 0.349 & 0.25 \\
\hline Reservation of e-paper (REP) & 0 & 0 & 0 & 0 & 0 & 1 & 0 & 0.163 & 0 & 0.163 & 0 & 0 & 0 & 0 & 0.157 & 0 & 0.140 & 0.168 & 0 \\
\hline Shopping cart (SC) & 0 & 0 & 0 & 0.25 & 0.25 & 0 & 0 & 0.297 & 0 & 0 & 0.25 & 0 & 0 & 0 & 0 & 0 & 0 & 0 & 0 \\
\hline Customized promotion $(\mathrm{CP})$ & 1 & 1 & 0.75 & 0.75 & 0.75 & 0 & 1 & 0.540 & 0.333 & 0.297 & 0 & 0.75 & 0 & 0 & 0.249 & 1 & 0.528 & 0.484 & 0.75 \\
\hline E-mail (EM) & 0 & 0 & 0 & 0 & 0 & 0 & 0 & 0.333 & 1 & 0 & 0 & 0 & 0.333 & 0.297 & 0.349 & 0 & 1 & 0.75 & 0 \\
\hline Message board (MB) & 0 & 1 & 0 & 0 & 0 & 0 & 0 & 0 & 0 & 0 & 0 & 0.140 & 0 & 0.163 & 0.168 & 0 & 0 & 0 & 0 \\
\hline Online users' forum (OUF) & 0 & 0 & 0 & 1 & 1 & 1 & 0 & 0 & 0 & 1 & 0.25 & 0.333 & 0.140 & 0 & 0.484 & 0 & 0 & 0 & 0 \\
\hline Online questionnaire (OQ) & 0 & 0 & 0 & 0 & 0 & 0 & 1 & 0.667 & 0 & 0 & 0.75 & 0.528 & 0.528 & 0.540 & 0 & 1 & 0 & 0.25 & 0 \\
\hline Advertising (AD) & 0.25 & 0 & 0 & 1 & 0.25 & 0.333 & 0 & 0 & 0.333 & 0 & 0 & 0 & 0 & 0 & 1 & 0 & 0.75 & 0.75 & 1 \\
\hline Lottery/prices $(\mathrm{L} / \mathrm{P})$ & 0.75 & 0 & 0 & 0 & 0 & 0 & 0.25 & 0 & 0.667 & 0 & 0 & 0.333 & 1 & 0.75 & 0 & 0.540 & 0 & 0.25 & 0 \\
\hline Coupons (CPN) & 0 & 0 & 0 & 0 & 0.75 & 0.667 & 0 & 1 & 0 & 1 & 0.667 & 0.667 & 0 & 0.25 & 0 & 0.163 & 0.25 & 0 & 0 \\
\hline Media promotion (MP) & 0 & 0 & 0 & 0 & 0 & 0 & 0.75 & 0 & 0 & 0 & 0.333 & 0 & 0 & 0 & 0 & 0.297 & 0 & 0 & 0 \\
\hline
\end{tabular}


Table A2. Weighted super matrix of analysis on the current situation of the company.

\begin{tabular}{|c|c|c|c|c|c|c|c|c|c|c|c|c|c|c|c|c|c|c|c|}
\hline \multirow{2}{*}{$\begin{array}{c}\text { Categories } \\
\text { Design indicators }\end{array}$} & \multicolumn{3}{|c|}{ Design } & \multicolumn{4}{|c|}{ Checking } & \multicolumn{4}{|c|}{ Service } & \multicolumn{4}{|c|}{ Interactive } & \multicolumn{4}{|c|}{ Promotion } \\
\hline & WA & SOI & WB & PS & PC & PR & DVR & $\mathrm{CD}$ & REP & SC & $\mathrm{CP}$ & EM & MB & OUF & OQ & $\mathrm{AD}$ & $\mathrm{L} / \mathrm{P}$ & CPN & MP \\
\hline Webpage announcement (WA) & 0 & 0 & 0.072 & 0 & 0 & 0 & 0 & 0 & 0 & 0 & 0 & 0.203 & 0 & 0 & 0 & 0.274 & 0.274 & 0.274 & 0 \\
\hline Simple operation of interface (SOI) & 0 & 0 & 0.216 & 0 & 0 & 0 & 0.085 & 0 & 0 & 0.261 & 0.261 & 0 & 0 & 0 & 0 & 0 & 0 & 0 & 0 \\
\hline Website browsing (WB) & 0 & 0.217 & 0 & 0 & 0 & 0 & 0 & 0 & 0 & 0 & 0 & 0 & 0 & 0 & 0.203 & 0 & 0 & 0 & 0 \\
\hline Product searching (PS) & 0 & 0.077 & 0 & 0 & 0.089 & 0.089 & 0 & 0 & 0 & 0.041 & 0.092 & 0.067 & 0.021 & 0 & 0.017 & 0 & 0 & 0 & 0 \\
\hline Price checking (PC) & 0 & 0.019 & 0 & 0.058 & 0 & 0.266 & 0.324 & 0 & 0 & 0.082 & 0.031 & 0.033 & 0.037 & 0.025 & 0.035 & 0 & 0 & 0 & 0 \\
\hline Product ranking (PR) & 0.070 & 0 & 0 & 0.105 & 0.266 & 0 & 0 & 0 & 0.167 & 0 & 0 & 0 & 0.068 & 0.101 & 0.048 & 0.181 & 0.181 & 0.181 & 0.288 \\
\hline Display of virtual reality (DVR) & 0.035 & 0 & 0 & 0.191 & 0 & 0 & 0 & 0 & 0 & 0 & 0 & 0 & 0 & 0 & 0 & 0 & 0 & 0 & 0 \\
\hline Customer database (CD) & 0 & 0 & 0.178 & 0 & 0 & 0 & 0 & 0 & 0.307 & 0.184 & 0.256 & 0.089 & 0.448 & 0.448 & 0.212 & 0 & 0.066 & 0.070 & 0.079 \\
\hline Reservation of e-paper (REP) & 0 & 0 & 0 & 0 & 0 & 0.281 & 0 & 0.090 & 0 & 0.056 & 0 & 0 & 0 & 0 & 0.056 & 0 & 0.028 & 0.033 & 0 \\
\hline Customized promotion $(\mathrm{CP})$ & 0.584 & 0.537 & 0.534 & 0.211 & 0.211 & 0 & 0.257 & 0.299 & 0.154 & 0.101 & 0 & 0.267 & 0 & 0 & 0.089 & 0.199 & 0.105 & 0.096 & 0.238 \\
\hline E-mail (EM) & 0 & 0 & 0 & 0 & 0 & 0 & 0 & 0.098 & 0.245 & 0 & 0 & 0 & 0.105 & 0.094 & 0.088 & 0 & 0.098 & 0.073 & 0 \\
\hline Message board (MB) & 0 & 0.151 & 0 & 0 & 0 & 0 & 0 & 0 & 0 & 0 & 0 & 0.035 & 0 & 0.052 & 0.042 & 0 & 0 & 0 & 0 \\
\hline Online users' forum (OUF) & 0 & 0 & 0 & 0.138 & 0.138 & 0.138 & 0 & 0 & 0 & 0.182 & 0.045 & 0.084 & 0.044 & 0 & 0.122 & 0 & 0 & 0 & 0 \\
\hline Online questionnaire (OQ) & 0 & 0 & 0 & 0 & 0 & 0 & 0.126 & 0.196 & 0 & 0 & 0.136 & 0.133 & 0.167 & 0.171 & 0 & 0.098 & 0 & 0.024 & 0 \\
\hline Advertising (AD) & 0.078 & 0 & 0 & 0.227 & 0.057 & 0.076 & 0 & 0 & 0.042 & 0 & 0 & 0 & 0 & 0 & 0.088 & 0 & 0.186 & 0.186 & 0.394 \\
\hline Lottery / prices $(\mathrm{L} / \mathrm{P})$ & 0.234 & 0 & 0 & 0 & 0 & 0 & 0.052 & 0 & 0.084 & 0 & 0 & 0.029 & 0.111 & 0.083 & 0 & 0.134 & 0 & 0.062 & 0 \\
\hline Coupons (CPN) & 0 & 0 & 0 & 0 & 0.170 & 0.151 & 0 & 0.152 & 0 & 0.094 & 0.062 & 0.059 & 0 & 0.028 & 0 & 0.040 & 0.062 & 0 & 0 \\
\hline Media promotion (MP) & 0 & 0 & 0 & 0 & 0 & 0 & 0.155 & 0 & 0 & 0 & 0.031 & 0 & 0 & 0 & 0 & 0.074 & 0 & 0 & 0 \\
\hline
\end{tabular}




\section{Appendix B}

Table A3. Unweighted super matrix of analysis on the expert questionnaire.

\begin{tabular}{|c|c|c|c|c|c|c|c|c|c|c|c|c|c|c|c|c|c|c|c|}
\hline \multirow{2}{*}{$\begin{array}{c}\text { Categories } \\
\text { Design indicators }\end{array}$} & \multicolumn{3}{|c|}{ Design } & \multicolumn{4}{|c|}{ Checking } & \multicolumn{4}{|c|}{ Service } & \multicolumn{4}{|c|}{ Interactive } & \multicolumn{4}{|c|}{ Promotion } \\
\hline & WA & SOI & WB & PS & PC & PR & DVR & $\mathrm{CD}$ & REP & SC & $\mathrm{CP}$ & EM & $\mathrm{MB}$ & OUF & $\mathrm{OQ}$ & $\mathrm{AD}$ & $\mathrm{L} / \mathrm{P}$ & $\mathrm{CPN}$ & MP \\
\hline Webpage announcement (WA) & 0 & 0 & 0.200 & 0 & 0 & 0 & 0 & 0 & 0 & 0 & 0 & 1 & 0 & 0 & 0 & 1 & 1 & 1 & 0 \\
\hline Simple operation of interface (SOI) & 0 & 0 & 0.800 & 0 & 0 & 0 & 1 & 0 & 0 & 1 & 1 & 0 & 0 & 0 & 0 & 0 & 0 & 0 & 0 \\
\hline Website browsing $(\mathrm{WB})$ & 0 & 1 & 0 & 0 & 0 & 0 & 0 & 0 & 0 & 0 & 0 & 0 & 0 & 0 & 1 & 0 & 0 & 0 & 0 \\
\hline Product searching (PS) & 0 & 0.667 & 0 & 0 & 0.833 & 0.667 & 0 & 0 & 0 & 0.667 & 0.667 & 0.667 & 0.558 & 0 & 0.582 & 0 & 0 & 0 & 0 \\
\hline Price checking $(\mathrm{PC})$ & 0 & 0.333 & 0 & 0.614 & 0 & 0.333 & 1 & 0 & 0 & 0.333 & 0.333 & 0.333 & 0.320 & 0.750 & 0.309 & 0 & 0 & 0 & 0 \\
\hline Product ranking (PR) & 0.200 & 0 & 0 & 0.117 & 0.167 & 0 & 0 & 0 & 1 & 0 & 0 & 0 & 0.122 & 0.250 & 0.109 & 1 & 1 & 1 & 1 \\
\hline Display of virtual reality (DVR) & 0.800 & 0 & 0 & 0.268 & 0 & 0 & 0 & 0 & 0 & 0 & 0 & 0 & 0 & 0 & 0 & 0 & 0 & 0 & 0 \\
\hline Customer database (CD) & 0 & 0 & 0.750 & 0 & 0 & 0 & 0 & 0 & 0.750 & 0.571 & 0.800 & 0.750 & 1 & 1 & 0.540 & 0 & 0.558 & 0.558 & 0.250 \\
\hline Reservation of e-paper (REP) & 0 & 0 & 0 & 0 & 0 & 1 & 0 & 0.540 & 0 & 0.286 & 0 & 0 & 0 & 0 & 0.297 & 0 & 0.320 & 0.320 & 0 \\
\hline Shopping cart (SC) & 0 & 0 & 0 & 0.333 & 0.333 & 0 & 0 & 0.163 & 0 & 0 & 0.200 & 0 & 0 & 0 & 0 & 0 & 0 & 0 & 0 \\
\hline Customized promotion $(\mathrm{CP})$ & 1 & 1 & 0.250 & 0.667 & 0.667 & 0 & 1 & 0.297 & 0.250 & 0.143 & 0 & 0.250 & 0 & 0 & 0.163 & 1 & 0.122 & 0.122 & 0.750 \\
\hline E-mail (EM) & 0 & 0 & 0 & 0 & 0 & 0 & 0 & 0.333 & 1 & 0 & 0 & 0 & 0.163 & 0.117 & 0.163 & 0 & 1 & 0.250 & 0 \\
\hline Message board (MB) & 0 & 1 & 0 & 0 & 0 & 0 & 0 & 0 & 0 & 0 & 0 & 0.540 & 0 & 0.614 & 0.540 & 0 & 0 & 0 & 0 \\
\hline Online users' forum (OUF) & 0 & 0 & 0 & 1 & 1 & 1 & 0 & 0 & 0 & 1 & 0.667 & 0.297 & 0.540 & 0 & 0.297 & 0 & 0 & 0 & 0 \\
\hline Online questionnaire (OQ) & 0 & 0 & 0 & 0 & 0 & 0 & 1 & 0.667 & 0 & 0 & 0.333 & 0.163 & 0.297 & 0.268 & 0 & 1 & 0 & 0.750 & 0 \\
\hline Advertising (AD) & 0.857 & 0 & 0 & 1 & 0.833 & 0.800 & 0 & 0 & 0.857 & 0 & 0 & 0 & 0 & 0 & 1 & 0 & 0.857 & 0.857 & 1 \\
\hline Lottery/ prices $(\mathrm{L} / \mathrm{P})$ & 0.143 & 0 & 0 & 0 & 0 & 0 & 0.667 & 0 & 0.143 & 0 & 0 & 0.333 & 1 & 0.250 & 0 & 0.297 & 0 & 0.143 & 0 \\
\hline Coupons (CPN) & 0 & 0 & 0 & 0 & 0.167 & 0.200 & 0 & 1 & 0 & 1 & 0.750 & 0.667 & 0 & 0.750 & 0 & 0.540 & 0.143 & 0 & 0 \\
\hline Media promotion (MP) & 0 & 0 & 0 & 0 & 0 & 0 & 0.333 & 0 & 0 & 0 & 0.250 & 0 & 0 & 0 & 0 & 0.163 & 0 & 0 & 0 \\
\hline
\end{tabular}


Table A4. Weighted super matrix of analysis on the expert questionnaire.

\begin{tabular}{|c|c|c|c|c|c|c|c|c|c|c|c|c|c|c|c|c|c|c|c|}
\hline \multirow{2}{*}{$\begin{array}{c}\text { Categories } \\
\text { Design indicators }\end{array}$} & \multicolumn{3}{|c|}{ Design } & \multicolumn{4}{|c|}{ Checking } & \multicolumn{4}{|c|}{ Service } & \multicolumn{4}{|c|}{ Interactive } & \multicolumn{4}{|c|}{ Promotion } \\
\hline & WA & SOI & WB & PS & PC & PR & DVR & $\mathrm{CD}$ & REP & SC & $\mathrm{CP}$ & EM & $\mathrm{MB}$ & OUF & OQ & $\mathrm{AD}$ & $\mathrm{L} / \mathrm{P}$ & $\mathrm{CPN}$ & MP \\
\hline Webpage announcement (WA) & 0 & 0 & 0.124 & 0 & 0 & 0 & 0 & 0 & 0 & 0 & 0 & 0.261 & 0 & 0 & 0 & 0.260 & 0.260 & 0.260 & 0 \\
\hline Simple operation of interface (SOI) & 0 & 0 & 0.497 & 0 & 0 & 0 & 0.263 & 0 & 0 & 0.263 & 0.263 & 0 & 0 & 0 & 0 & 0 & 0 & 0 & 0 \\
\hline Website browsing (WB) & 0 & 0.291 & 0 & 0 & 0 & 0 & 0 & 0 & 0 & 0 & 0 & 0 & 0 & 0 & 0.261 & 0 & 0 & 0 & 0 \\
\hline Product searching (PS) & 0 & 0.309 & 0 & 0 & 0.473 & 0.378 & 0 & 0 & 0 & 0.279 & 0.279 & 0.276 & 0.313 & 0 & 0.241 & 0 & 0 & 0 & 0 \\
\hline Price checking (PC) & 0 & 0.155 & 0 & 0.349 & 0 & 0.189 & 0.419 & 0 & 0 & 0.140 & 0.140 & 0.138 & 0.179 & 0.420 & 0.128 & 0 & 0 & 0 & 0 \\
\hline Product ranking (PR) & 0.124 & 0 & 0 & 0.067 & 0.095 & 0 & 0 & 0 & 0.568 & 0 & 0 & 0 & 0.068 & 0.140 & 0.045 & 0.415 & 0.415 & 0.415 & 0.610 \\
\hline Display of virtual reality (DVR) & 0.496 & 0 & 0 & 0.152 & 0 & 0 & 0 & 0 & 0 & 0 & 0 & 0 & 0 & 0 & 0 & 0 & 0 & 0 & 0 \\
\hline Customer database (CD) & 0 & 0 & 0.284 & 0 & 0 & 0 & 0 & 0 & 0.163 & 0.091 & 0.128 & 0.130 & 0.234 & 0.234 & 0.093 & 0 & 0.098 & 0.098 & 0.064 \\
\hline Reservation of e-paper (REP) & 0 & 0 & 0 & 0 & 0 & 0.217 & 0 & 0.271 & 0 & 0.046 & 0 & 0 & 0 & 0 & 0.051 & 0 & 0.056 & 0.056 & 0 \\
\hline Shopping cart (SC) & 0 & 0 & 0 & 0.072 & 0.072 & 0 & 0 & 0.082 & 0 & 0 & 0.032 & 0 & 0 & 0 & 0 & 0 & 0 & 0 & 0 \\
\hline Customized promotion $(\mathrm{CP})$ & 0.237 & 0.177 & 0.095 & 0.145 & 0.145 & 0 & 0.160 & 0.149 & 0.054 & 0.023 & 0 & 0.043 & 0 & 0 & 0.028 & 0.175 & 0.021 & 0.021 & 0.193 \\
\hline E-mail (EM) & 0 & 0 & 0 & 0 & 0 & 0 & 0 & 0.065 & 0.084 & 0 & 0 & 0 & 0.018 & 0.013 & 0.013 & 0 & 0.061 & 0.015 & 0 \\
\hline Message board (MB) & 0 & 0.068 & 0 & 0 & 0 & 0 & 0 & 0 & 0 & 0 & 0 & 0.044 & 0 & 0.069 & 0.044 & 0 & 0 & 0 & 0 \\
\hline Online users' forum (OUF) & 0 & 0 & 0 & 0.084 & 0.084 & 0.084 & 0 & 0 & 0 & 0.062 & 0.041 & 0.024 & 0.060 & 0 & 0.024 & 0 & 0 & 0 & 0 \\
\hline Online questionnaire (OQ) & 0 & 0 & 0 & 0 & 0 & 0 & 0.062 & 0.129 & 0 & 0 & 0.021 & 0.013 & 0.033 & 0.030 & 0 & 0.061 & 0 & 0.046 & 0 \\
\hline Advertising (AD) & 0.123 & 0 & 0 & 0.132 & 0.110 & 0.105 & 0 & 0 & 0.113 & 0 & 0 & 0 & 0 & 0 & 0.069 & 0 & 0.077 & 0.077 & 0.132 \\
\hline Lottery/ prices $(\mathrm{L} / \mathrm{P})$ & 0.021 & 0 & 0 & 0 & 0 & 0 & 0.065 & 0 & 0.019 & 0 & 0 & 0.023 & 0.094 & 0.023 & 0 & 0.027 & 0 & 0.013 & 0 \\
\hline Coupons (CPN) & 0 & 0 & 0 & 0 & 0.022 & 0.026 & 0 & 0.305 & 0 & 0.097 & 0.073 & 0.046 & 0 & 0.070 & 0 & 0.049 & 0.013 & 0 & 0 \\
\hline Media promotion (MP) & 0 & 0 & 0 & 0 & 0 & 0 & 0.032 & 0 & 0 & 0 & 0.024 & 0 & 0 & 0 & 0 & 0.015 & 0 & 0 & 0 \\
\hline
\end{tabular}




\section{References}

1. Department of Commerce in Ministry of Economic Affairs, R.O. C. 2013 E-Commerce Yearbook of the Republic of China; Institute for Information Industry: Taipei, Taiwan, 2013.

2. Tapscott, D.; Lowy, A.; Ticoll, D. Blueprint to the Digital Economy: Creating Wealth in the Era of E-business; McGraw-Hill Professional: New York, NY, USA, 1998.

3. Amit, R.; Zott, C. Creating value through business model innovation. MIT Sloan Manag. Rev. 2012, 53, 41-49.

4. Shane, S.; Venkataraman, S. The promise of entrepreneurship as a field of research. Acad. Manag. Rev. 2000, 25, 217-226. [CrossRef]

5. Westerlund, M.; Leminen, S.; Rajahonka, M. Designing Business Models for the Internet of Things. Technol. Innov. Manag. Rev. 2014, 4, 5-14.

6. Wirtz, B.W.; Schilke, O.; Ullrich, S. Strategic Development of Business Models: Implications of the Web 2.0 for Creating Value on the Internet. Long Range Plan. 2010, 43, 272-290. [CrossRef]

7. Fuentes-Blasco, M.; Saura, I.-G.; Berenguer-Contrí, G.; Moliner-Velázquez, B. Measuring the antecedents of e-loyalty and the effect of switching costs on website. Serv. Ind. J. 2010, 30, 1837-1852. [CrossRef]

8. Park, H.; Reber, B.H. Relationship building and the use of Web sites: How Fortune corporations use their Web sites to build relationships. Public Relat. Rev. 2008, 34, 409-411. [CrossRef]

9. Pine, B.J.; Peppers, D.; Rogers, M. Do You Want to Keep Your Customers Forever?; Harvard Business Press: Boston, MA, USA, 2010.

10. Fowler, D.; Pitta, D.; Leventhal, R.C. Technological advancements and social challenges for one-to-one marketing. J. Consum. Mark. 2013, 30, 509-516. [CrossRef]

11. Kassim, N.; Abdullah, N.A. The effect of perceived service quality dimensions on customer satisfaction, trust, and loyalty in e-commerce settings: A cross cultural analysis. Asia Pac. J. Mark. Logist. 2010, 22, 351-371. [CrossRef]

12. Kollmann, T. What is e-Entrepreneurship?-Fundamentals of company founding in the net economy. Int. J. Technol. Manag. 2006, 33, 322-340. [CrossRef]

13. Razak, M.Z.A.; Ilias, A. Seven Unique Differentiation Strategies to Online Businesses: A Comprehensive Review of Malaysia Airline System (MAS). J. Intern. Bank. Commerc. 2011, 16, 1-16.

14. Chen, Y.; Zhang, G.; Hu, D.; Fu, C. Customer segmentation based on survival character. J. Intell. Manuf. 2007, 18, 513-517. [CrossRef]

15. Kuo, T.C.; Hsu, C.W.; Li, J.Y. Developing a Green Supplier Selection Model by Using the DANP with VIKOR. Sustainability 2015, 7, 1661-1689. [CrossRef]

16. Yesil, M. Creating the Virtual Store; John Wiley \& Sons: New York, NY, USA, 1997.

17. Brynjolfsson, E.; Smith, M.D. Frictionless commerce? A comparison of Internet and conventional retailers. Manag. Sci. 2000, 46, 563-585. [CrossRef]

18. Daily, C.M.; McDougall, P.P.; Covin, J.G.; Dalton, D.R. Governance and strategic leadership in entrepreneurial firms. J. Manag. 2002, 28, 387-412. [CrossRef]

19. Sharma, P.; Chrisman, S.J.J. Toward a Reconciliation of the Definitional Issues in the Field of Corporate Entrepreneurship; Springer Berlin Heidelberg: New York, NY, USA, 2007; pp. 83-103.

20. Kollmann, T. Marketing for Electronic Market Places-the Relevance of Two "Critical Points of Success". Electron. Mark. 1998, 8, 36-39. [CrossRef]

21. Liu, C.; Arnett, K.P.; Capella, L.M.; Beatty, R.C. Web sites of the Fortune 500 companies: Facing customers through home pages. Inf. Manag. 1997, 31, 335-345. [CrossRef]

22. Ng, H.I.; Pan, Y.J.; Wilson, T. Business use of the World Wide Web: A report on further investigations. Int. J. Inf. Manag. 1998, 18, 291-314. [CrossRef]

23. Esrock, S.L.; Leichty, G.B. Organization of corporate web pages: Publics and functions. Public Relat. Rev. 2000, 26, 327-344. [CrossRef]

24. Angehrn, A. Designing mature Internet business strategies: The ICDT model. Eur. Manag. J. 1997, 15, 361-369. [CrossRef]

25. Burgess, S.; Sellitto, C.; Karanasios, S. A Model of ICDT Internet Flows on Mobile Devices for the Travel and Tourism Consumer. Tour. Anal. 2012, 17, 705-719. [CrossRef]

26. Wang, Y.; Zhou, C. Comparative Study of Online Trading Patterns Based on FOMMAD and ICDT. In Proceedings of the 2012 3rd International Conference on E-Business and E-Government-Volume 05, Shanghai, China, 11-13 May 2012; IEEE Computer Society: Washington, DC, USA, 2012. 
27. Lee, T.R.; Lee, J.S.; Muhos, M. Formulating a Business Management Strategy for E-shopping Websites Using Management Analysis. J. Bus. 2013, 15, 411-434.

28. Seybold, P.B.; Marshak, R.T.; Lewis, J.M. The Customer Revolution; Random House: New York, NY, USA, 2001.

29. Kollmann, T. Attitude, adoption or acceptance? Measuring the market success of telecommunication and multimedia technology. Int. J. Bus. Perform. Manag. 2004, 6, 133-152. [CrossRef]

30. Szymanski, D.M.; Hise, R.T. E-satisfaction: An initial examination. J. Retail. 2000, 76, 309-322. [CrossRef]

31. Liang, T.P.; Lai, H.J. Effect of store design on consumer purchases: An empirical study of on-line bookstores. Inf. Manag. 2002, 39, 431-444. [CrossRef]

32. Jensen, J.F. Interactivity-tracking a new concept. In Communication, Computer Media and the Internet: A Reader; Oxford University Press: Oxford, UK, 2000.

33. Rafaeli, S. Interactivity: From new media to communication. Sage Annu. Rev. Commun. Res. Adv. Commun. Sci. 1988, 16, 110-134.

34. Srinivasan, S.S.; Anderson, R.; Ponnavolu, K. Customer loyalty in e-commerce: An exploration of its antecedents and consequences. J. Retail. 2002, 78, 41-50. [CrossRef]

35. Orihuela, J.L. Blogging and the e-Communication Paradigms: 10 principles of the new media scenario. Comun. Soc. 2012, 5, 125.

36. Ghose, S.; Dou, W. Interactive Functions and their Impacts on the Appeal of Internet Presence Sites. J. Adv. Res. $1998,38,29-44$.

37. Parasuraman, A.; Zeithaml, V.A.; Malhotra, A. ES-QUAL a multiple-item scale for assessing electronic service quality. J. Serv. Res. 2005, 7, 213-233. [CrossRef]

38. Saaty, T.L. Decision Making with Dependence and Feedback: The Analytic Network Process; RWS Publications: Pittsburgh, PA, USA, 1996.

39. Saaty, T.L. Theory and Applications of the Analytic Network Process: Decision Making with Benefits, Opportunities, Costs, and Risks; RWS publications: Pittsburgh, PA, USA, 2005.

40. Saaty, T.L.; Vargas, L. Decision Making with the Analytic Network Process, Economics, Political, Social and Technological Applications with Benefits, Opportunities, Costs, and Risks; Springer: Berlin, Germany, 2006.

41. Saaty, T.L. The modern science of multicriteria decision making and its practical applications: The AHP/ANP approach. Oper. Res. 2013, 61, 1101-1118. [CrossRef]

42. Saaty, T.L. The Analytic Hierarchy Process, Planning, Priority Setting, Resource Allocation; McGraw-Hill: New York, NY, USA, 1980.

43. Jharkharia, S.; Shankar, R. Selection of logistics service provider: An analytic network process (ANP) approach. Omega 2007, 35, 274-289. [CrossRef]

44. Dargi, A.; Anjomshoae, A.; Galankashi, M.R.; Memari, A.; Tap, M.B. Supplier Selection: A Fuzzy-ANP Approach. Procedia Comput. Sci. 2014, 31, 691-700. [CrossRef]

45. Lami, I.M.; Abastante, F. Decision making for urban solid waste treatment in the context of territorial conflict: Can the Analytic Network Process help? Land Use Policy 2014, 41, 11-20. [CrossRef]

46. Lami, I.M.; Abastante, F.; Bottero, M.; Masala, E.; Pensa, S. Integrating multicriteria evaluation and data visualization as a problem structuring approach to support territorial transformation projects. EURO J. Decis. Process. 2014, 2, 281-312. [CrossRef]

47. Gölcük, İ.; Baykasoğlu, A. An analysis of DEMATEL approaches for criteria interaction handling within ANP. Expert Syst. Appl. 2016, 46, 346-366. [CrossRef]

48. Karpak, B.; Topcu, I. Small medium manufacturing enterprises in Turkey: An analytic network process framework for prioritizing factors affecting success. Int. J. Prod. Econ. 2010, 125, 60-70. [CrossRef]

49. Abdi, M.R.; Labib, A.W. Performance evaluation of reconfigurable manufacturing systems via holonic architecture and the analytic network process. Int. J. Prod. Res. 2011, 49, 1319-1335. [CrossRef]

50. Ferretti, V.; Pomarico, S. Ecological land suitability analysis through spatial indicators: An application of the Analytic Network Process technique and Ordered Weighted Average approach. Ecol. Ind. 2013, 34, 507-519. [CrossRef]

(C) 2016 by the authors; licensee MDPI, Basel, Switzerland. This article is an open access article distributed under the terms and conditions of the Creative Commons Attribution (CC-BY) license (http://creativecommons.org/licenses/by/4.0/). 